\title{
Sensitivitas Multiplex-Polymerase Chain Reaction Gen 12S rRNA dalam Mendeteksi Pemalsuan Daging Sapi dengan Daging Babi, Anjing dan Tikus
}

\author{
(SENSITIVITY OF MULTIPLEX- POLYMERASE CHAIN REACTION TARGETING 12S \\ rRNA GENE IN DETECTING BEEF ADULTERATION WITH PORK, DOG AND RAT)
}

\author{
Irma Khikmawati ${ }^{1}$, Slamet Diah Volkandari ${ }^{2}$, \\ Zakaria Husein Abdurrahman ${ }^{3}$, Ahmad Pramono ${ }^{1}$, \\ Muhammad Cahyadi ${ }^{1,4^{*}}$
}

${ }^{1}$ Program Studi Peternakan, Fakultas Pertanian, Universitas Sebelas Maret,

Jl. Ir Sutami 36A Kentingan, Surakarta, Jawa Tengah, Indonesia 57126

${ }^{2}$ Pusat Riset Bioteknologi,Organisasi Riset Ilmu Pengetahuan Hayati,

Badan Riset dan Inovasi Nasional (BRIN)

Jl. Raya Bogor KM 46, Cibinong, Bogor, Jawa Barat Indonesia 16911,

${ }^{3}$ Program Studi Peternakan, Fakultas Peternakan, Universitas Boyolali,

Jl. Pandanaran No.405, Dusun 1, Winong, Boyolali, Jawa Tengah, Indonesia 57315,

${ }^{4}$ Halal Research Center and Services, Lembaga Penelitian dan Pengabdian Masyarakat,

Universitas Sebelas Maret, Jl. Ir Sutami 36A Kentingan,

Surakarta, Jawa Tengah, Indonesia 57126,

*Email: mcahyadi@staff.uns.ac.id

\begin{abstract}
Beef and its processed products are subject to be adulterated. Changes in halal meat status can be caused by mixing with other species. Besides, these conditions can be a serious cause of health risks, such as food poisoning, sources of disease, or allergies. Effective control is needed to ensure the authenticity and safety of meat. Molecular detection using multiplex-PCR is commonly used because of its efficiency and sensitivity. The aim of this study was to evaluate multiplex-PCR sensitivity targeting mtDNA 12S rRNA gene in detecting cattle, dog, porcine, and rat. Each DNA template was made for six concentrations, namely $25 ; 10 ; 1 ; 0.1 ; 0.01 ; 0.001 \mathrm{ng} / \mathrm{\mu L}$ for simplex- and multiplex-PCR. The result of sensitivity for simplex-PCR showed that the pair of primer 12S rRNA gene could amplify target species of cattle, dog, porcine, and rat accurately to a concentration of $0.001 \mathrm{ng} / \mathrm{\mu L}$. The multiplex-PCR sensitivity test for the $12 \mathrm{~S}$ rRNA gene could amplify the target species of cattle, dog, porcine up to $0.001 \mathrm{ng} / \mathrm{\mu L}$ and in rat up to $1 \mathrm{ng} / \mathrm{\mu L}$. Thus, this methods can be used as an alternative solution for halal studies and food label verification.
\end{abstract}

Keywords: $12 \mathrm{~S}$ rRNA gene; halal meat; multiplex-PCR; detection sensitivity

\begin{abstract}
ABSTRAK
Daging sapi dan olahannya merupakan sasaran pemalsuan. Pelaku pemalsuan daging sapi mencampur daging sapi dengan daging spesies hewan lain, sehingga berakibat pada berubahnya status kehalalan daging. Selain itu, kondisi tersebut dapat menjadi penyebab serius pada risiko kesehatan, seperti potensi keracunan, sumber penyakit maupun alergi. Pengawasan yang efektif diperlukan guna menjamin keaslian dan keamanan daging. Metode deteksi secara molekuler yang umum digunakan adalah multiplex-PCR karena efisien dan sensitif. Tujuan penelitian ini untuk mendeteksi sensitivitas multiplex-PCR primer gen $12 \mathrm{~S}$ rRNA yang spesifik untuk spesies sapi, anjing, babi, dan tikus. Template DNA dibuat masing-masing enam konsentrasi, yaitu $25 ; 10 ; 1 ; 0,1 ; 0,01 ; 0,001 \mathrm{ng} / \mu \mathrm{L}$ untuk proses simplex dan multiplex-PCR. Hasil uji sensitivitas menggunakan metode simplex-PCR menunjukkan bahwa primer gen $12 \mathrm{~S}$ rRNA dapat mengamplifikasi spesies sapi, anjing, babi, dan tikus dengan akurat hingga konsentrasi $0,001 \mathrm{ng} / \mathrm{uL}$. Pengujian sensitivitas multiplex-PCR gen $12 \mathrm{~S}$ rRNA dapat mengamplifikasi spesies sapi, anjing, babi hingga konsentrasi 0,001 ng/ $\mathrm{LL}$ dan pada spesies tikus hingga konsentrasi $1 \mathrm{ng} /$ $\mu \mathrm{L}$. Metode PCR ini dapat digunakan sebagai solusi alternatif dalam studi halal dan verifikasi label pangan.
\end{abstract}

Kata-kata kunci: gen 12S rRNA; daging halal; multiplex-PCR; sensitivitas deteksi 


\section{PENDAHULUAN}

Daging sapi dan olahannya merupakan salah satu sasaran pemalsuan oleh oknum produsen. Kasus pemalsuan daging umumnya dilatarbelakangi oleh faktor ekonomi (Nida et $a l ., 2020)$ dan oleh kontaminasi secara tidak sengaja saat proses pengolahan meskipun dalam jumlah sedikit (Naaum et al., 2018). Status halal pada daging sapi dapat berubah apabila tercampur dengan spesies daging yang terlarang dalam Islam (haram) berupa daging anjing, daging tikus maupun daging babi. Harga daging sapi lebih mahal apabila dibandingkan dengan harga daging lain. Menurut Kumparan Bisnis (2018) bahwa harga daging anjing di pasaran mencapai Rp 20.000/kg serta dilaporkan oleh Tribun Manado (2020) harga daging babi paling tinggi adalah Rp 50.000/kg. Harga tersebut lebih rendah daripada daging sapi yaitu $R p$ 115.200/ kg (PIHPS Nasional, 2021).

Pemalsuan pangan telah menjadi permasalahan pada skala global sehingga konsumen perlu lebih waspada. Pengaruh pada pemalsuan daging tidak hanya pada risiko kesehatan, seperti potensi keracunan, sumber penyakit maupun alergi (Spink dan Moyer, 2011), namun lebih lanjut dapat berimbas pada hak konsumen dari sisi ekonomi, kepercayaan, hingga agama. Meningkatnya permintaan dalam standarisasi kualitas pangan serta kepedulian pada konsumen maka dilakukan deteksi untuk komposisi bahan pangan (El Sheikha, 2017). Metode deteksi yang spesifik dan sensitif diperlukan guna mengetahui komposisi spesies daging pada produk pangan.

Deteksi pemalsuan daging dapat dilakukan melalui teknik molekuler berbasis DNA, salah satunya dengan multiplex-PCR (multiplex polymerase chain reaction) yang umum digunakan, karena alasan hemat waktu, sensitif, dan mampu melakukan reaksi untuk beberapa sampel spesies dalam satu tabung. Senyawa DNA terbukti cukup stabil terhadap perlakuan suhu tinggi, tekanan serta perlakuan kimia. Aplikasi multiplex-PCR seringkali menargetkan DNA mitokondria karena tingginya hasil salinan DNA per sel serta stabil (Kumar et al., 2015). Sekuen DNA mitokondria, seperti fragmen gen $12 \mathrm{~S}$ rRNA telah digunakan untuk deteksi spesies pada daging oleh Cahyadi et al. (2018), Cahyadi et al. (2019) dan Cahyadi et al. (2020). Fragmen gen mitokondria $12 \mathrm{~S}$ rRNA diketahui mampu mendeteksi hingga konsentrasi 0,0125 ng (Dalmasso et al., 2004).
Primer dari gen $12 \mathrm{~S}$ rRNA memiliki variasi rendah dalam satu spesies dan memiliki variasi besar antar spesies. Meskipun metode multiplexPCR gen 12S rRNA telah banyak digunakan untuk deteksi berbagai spesies (Li et al., 2019), namun belum ditemukan pengujian sensitivitas pada spesies sapi, anjing, babi dan tikus dalam satu kali reaksi. Tujuan penelitian ini adalah mencoba menerapkan multiplex-PCR primer gen $12 \mathrm{~S}$ rRNA sebagai gen penanda dalam uji sensitivitas terhadap berbagai konsentrasi DNA spesies sapi, anjing, babi dan tikus got, sehingga ditemukan konsentrasi minimum yang terdeteksi.

\section{METODE PENELITIAN}

\section{Koleksi dan Preparasi Sampel Daging}

Daging sapi (Bos taurus), daging babi (Sus scrofa) dan daging anjing (Canis lupus familiaris) dikoleksi dari pasar tradisional di Kota Surakatra. Daging tikus got (Rattus norvegicus) didapatkan dengan mencari tikus got di Kota Surakarta. Tikus got kemudian dikorbankan nyawanya/dimatikan dengan cara meletakkan tikus-tikus tersebut di dalam wadah tertutup dan diberi chloroform. Pembedahan dilakukan setelah tikus benar-benar mati. Sampel diletakkan pada plastik ziplock dalam kondisi double dan disimpan pada freezer dengan suhu $-20^{\circ} \mathrm{C}$.

\section{Ekstraksi DNA}

Ekstraksi DNA dilakukan menggunakan metode Salt oleh Cawthorn et al. (2011). Sampel daging $(50 \mathrm{mg}$ ) dilarutkan pada $400 \mu \mathrm{L}$ lisis buffer terdiri atas 0,4 M NaCl, $2 \mathrm{M}$ ethylene diamine tetra acetic acid (EDTA) dengan $\mathrm{pH}$ 8,0; $10 \mathrm{mM}$ Tris- $\mathrm{HCl} \mathrm{pH}$ 8,0; 20\% sodium dodesil sulfat (SDS) sebanyak $40 \mu \mathrm{L}$ dan proteinase-K $20 \mathrm{mg} / \mathrm{mL}$ sebanyak $20 \mu \mathrm{L}$ lalu divortex. Sampel diinkubasi $\left(65^{\circ} \mathrm{C}, 1\right.$ jam) kemudian ditambahkan $\mathrm{NaCl} \quad 6 \quad \mathrm{M}$ sebanyak $300 \mu \mathrm{L}$ dan divortex selama 30 detik. Sampel disentrifugasi (10.000 rpm, 30 menit). Cairan bening diambil, kemudian dipindah pada tube baru. Isopropanol ditambahkan 1:1 dan divortex. Sampel diinkubasi $\left(-20^{\circ} \mathrm{C}, 1 \mathrm{jam}\right)$, kemudian disentrifugasi pada 10.000 rpm selama 20 menit. Cairan supernatan dibuang dan ditambahkan $1 \mathrm{~mL}$ etanol 70\%. Sampel disentrifugasi (10.000 rpm, 5 menit) lalu cairan supernatan dibuang. Sampel dikering-kan, kemudian ditambahkan Tris-EDTA (TE) buffer $100 \mu \mathrm{L}$ menggunakan tube baru. 


\section{Kuantifikasi dan Pengenceran DNA}

Kuantifikasi DNA dilakukan menurut panduan NanoPhotometer (P-Class ${ }^{\circledR}$, Implen, Munchen, Jerman) . Pengecekan menggunakan sampel sebanyak $3 \mu \mathrm{L}$, kemudian pada perangkat luak/software dimasukkan nilai panjang gelombang A260/A280. Hasil ekstraksi DNA masing-masing spesies diencerkan dengan aquabidest $\left(\mathrm{ddH}_{2} \mathrm{O}\right)$ hingga diperoleh konsentrasi $25 \mathrm{ng} / \mu \mathrm{L}$. Sampel diencerkan kembali hingga diperoleh konsentrasi $10 ; 1 ; 0,1 ; 0,01 ;$ dan 0,001 $\mathrm{ng} / \mu \mathrm{L}$ untuk masing-masing spesies. Pengenceran sampel dilakukan berdasarkan Demeo (1996) yaitu konsentrasi awal dikalikan dengan volume awal akan memiliki hasil yang sama dengan konsentrasi akhir dikalikan dengan volume akhir atau $\mathrm{C}_{i}, \mathrm{~V}_{i}=\mathrm{C}_{f}, \mathrm{~V}_{f}$.

\section{Simplex-dan Multiplex-PCR}

Proses simplex-PCR dan multiplex-PCR dilakukan pada mesin PCR (GeneAmp ${ }^{\circledR}$ PCR System 9700, Applied Biosystems, Singapura). Reaksi mengunakan primer gen 12S rRNA (Cahyadi et al., 2018; Cahyadi et al., 2019) disajikan pada Tabel 1 dengan total volume reaksi $25 \mu \mathrm{L}$, terdiri atas Master Mix 12,5 $\mu \mathrm{L}$ bioline (MyTaq ${ }^{\mathrm{TM}}$ HS Red Mix, London, Inggris), $10 \mu \mathrm{M}$ primer untuk masing-masing spesies, $25 ; 10 ; 1 ; 0,1 ; 0,01 ; 0,001 \mathrm{ng} / \mu \mathrm{L}$ template DNA, serta penambahan aquabidest menyesuaikan hingga volume total menjadi $25 \mu \mathrm{L}$. Reaksi diawali tahap inisiasi denaturasi pada $95^{\circ} \mathrm{C}$ selama 3 menit, dilanjutkan 35 siklus denaturasi $\left(95^{\circ} \mathrm{C}, 15\right.$ detik), kemudian proses annealing $\left(58^{\circ} \mathrm{C}, 30\right.$ detik), extention $\left(72^{\circ} \mathrm{C}, 30\right.$ detik), serta final extention $\left(72^{\circ} \mathrm{C}\right.$, 10 menit). Produk PCR dielektroforesis menggunakan agarose gel $2 \%$ dan divisualisasi dengan gel document (Glite UV
Gel Doc System ${ }^{\circledR}$, Pacific Image Electronic Co., Ltd., New Taipei City, Taiwan).

\section{HASIL DAN PEMBAHASAN}

\section{Amplifikasi Simplex-PCR}

Gen 12S rRNA berhasil mengamplifikasi target spesies pada masing-masing spesies sapi $155 \mathrm{bp}$, spesies anjing $244 \mathrm{bp}$, spesies babi 357 bp dan spesies tikus 491 bp menggunakan simplex-PCR. Sensitivitas yang mampu terdeteksi hingga konsentrasi 0,001 ng/ $\mu \mathrm{L}$ (Gambar 1). Hasil visualisasi simplex-PCR pada template DNA spesies sapi (Gambar 1 (A), kolom S1-S6), spesies anjing (Gambar 1 (B), kolom N1-N6), spesies babi (Gambar 1 (C), kolom B1-B6) dan spesies tikus (Gambar 1 (D), kolom T1T6) dengan berbagai konsentrasi menunjukkan adanya variasi berupa terang ke redup. Visualisasi DNA pada spesies sapi dan anjing dengan konsentrasi $25 ; 10 ; 1$; dan $0,1 \mathrm{ng} / \mathrm{\mu L}$ menghasilkan pita yang jelas serta terang dan pada konsentrasi 0,01 dan $0,001 \mathrm{ng} / \mathrm{\mu L}$ tampak redup. Visualisasi template DNA spesies babi pada konsentrasi $25 ; 10 ; 1 ; 0,1$; dan 0,01 menghasilkan pita DNA yang terang serta jelas dan pada konsentrasi $0,001 \mathrm{ng} / \mathrm{\mu L}$ tampak redup. Konsentrasi template DNA spesies tikus pada $25 ; 10 ; 1,0 \mathrm{ng} / \mathrm{\mu L}$ menghasilkan pita yang terang, pada konsentrasi $0,1 \mathrm{ng} / \mu \mathrm{L}$ menghasilkan pita yang agak redup, serta pada 0,01 dan 0,001 $\mathrm{ng} / \mu \mathrm{L}$ pita DNA tampak redup. Uji sensitivitas simplex-PCR primer gen $12 \mathrm{~S}$ rRNA pada spesies sapi, anjing, babi, dan tikus dapat mengam-plifikasi dan sensitif hingga konsentrasi $0,001 \quad \mathrm{ng} / \mu \mathrm{L}$. Penggunaan berbagai primer dalam uji

Tabel 1. Pasangan primer fragmen DNA mitokondria gen 12S rRNA

\begin{tabular}{lllc}
\hline Spesies & & Primer $\left(5^{\prime}-3^{\prime}\right)$ & Panjang $(\mathrm{bp})$ \\
\hline Sapi & UF & ACCGCGGTCATACGATTAAC & 155 \\
& R & AGTGCGTCGGCTATTGTAGG & \\
Anjing & UF & ACCGCGGTCATACGATTAAC & 244 \\
& R & TCCTCTGGCGATTATTTTGTTG & \multirow{2}{*}{357} \\
Babi & UF & ACCGCGGTCATACGATTAAC & \multirow{2}{*}{ Tikus } \\
& R & CGGTATGTACGTGCCTCAGA & \\
& R & ACCGCGGTCATACGATTAAC & \\
\hline
\end{tabular}

Keterangan: $\mathrm{UF}=$ Primer universal forward $\mathrm{R}=$ Primer reverse 

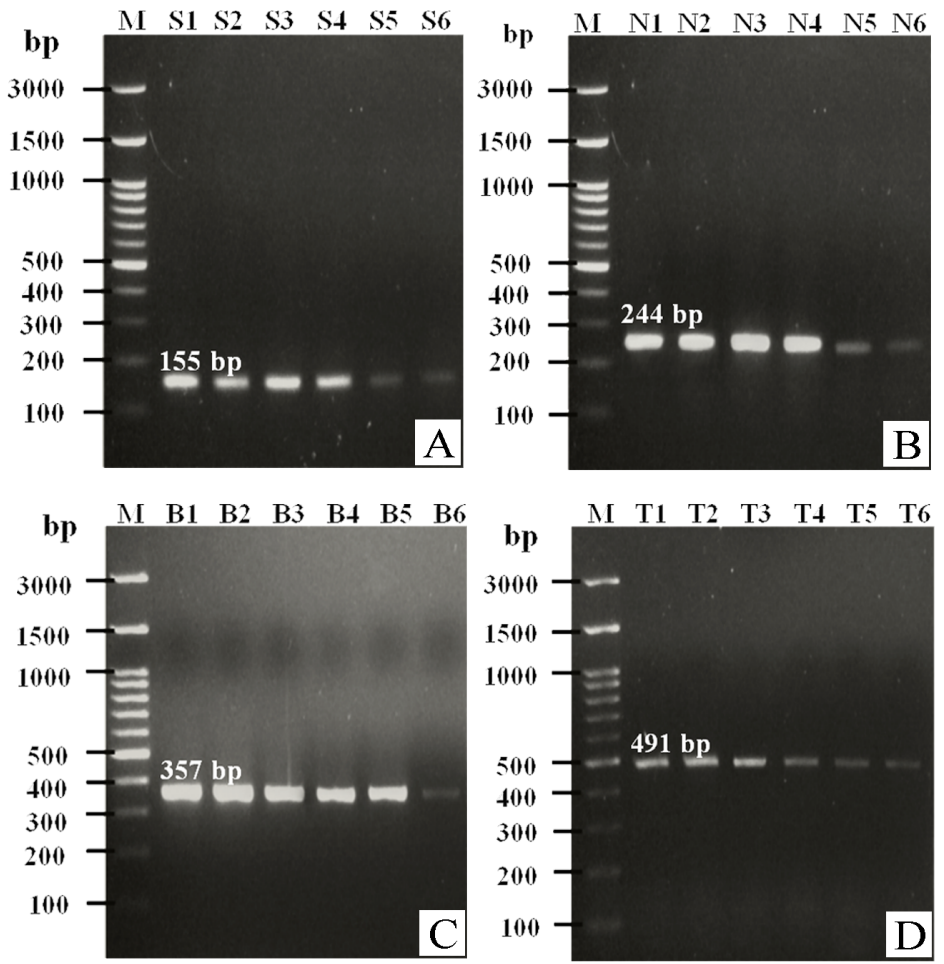

Gambar 1. Visualisasi pengujian sensitivitas simplex-PCR. Marker (M), kolom S1-S6: DNA spesies sapi $25 ; 10 ; 1 ; 0,1 ; 0,01$; dan $0,001 \mathrm{ng} / \mu \mathrm{L}(\mathrm{A})$, kolom N1-N6: DNA spesies anjing 25; 10; $1 ; 0,1 ; 0,01$; dan 0,001 ng/ $\mathrm{LL}$ (B), kolom B1-B6: DNA spesies babi 25; 10; 1; 0,1; 0,01; dan 0,001 ng/ $\mathrm{L}(\mathrm{C})$, kolom T1-T6: DNA spesies tikus 25; 10; 1; 0,1;0,01; dan $0,001 \mathrm{ng} / \mu \mathrm{L}(\mathrm{D})$.

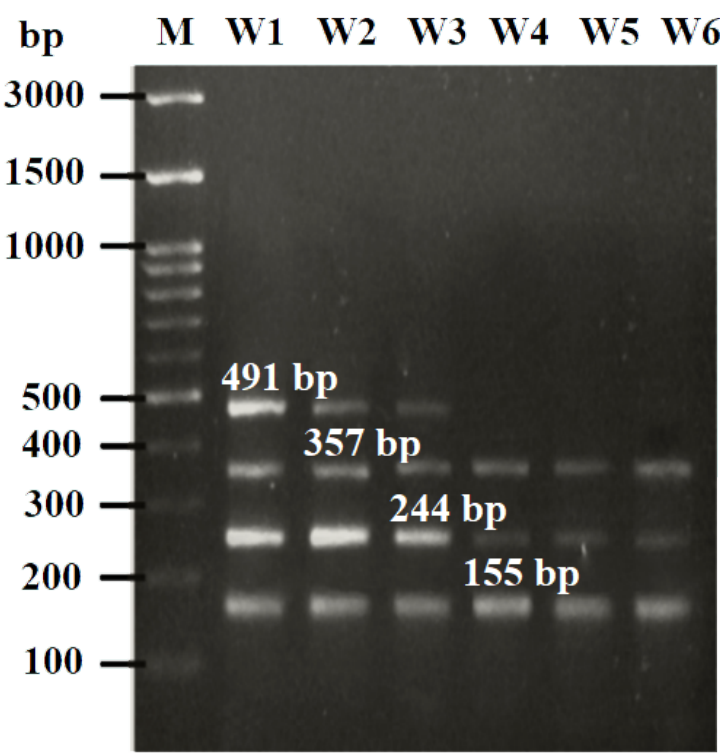

Gambar 2. Visualisasi pengujian sensitivitas multiplex-PCR empat spesies hewan. Marker (M), kolom W1-W6: template DNA dengan konsentrasi 25; 10; 1; 0,1;0,01; dan 0,001 ng/ $\mu \mathrm{L}$. sensitivitas terhadap template DNA spesies sapi, anjing, babi, dan tikus telah dilakukan pada penelitian sebelumnya. Sensitivitas primer gen 12S rRNA pada spesies sapi memiliki limit deteksi 0,5 ng (Yin et al., 2009). Pengujian sensitivitas pada spesies babi menggunakan primer gen Cytochrome Oxidase Subunit 1 (COI) mampu mendeteksi hingga 0,001 ng (Wang et $a l ., 2019)$ dan primer gen cyt b dengan metode Eva Green real-time PCR hingga 0,00001 ng/ $\mu \mathrm{L}$ (Lubis et al., 2018). Pengujian sensitivitas oleh Matsunaga et al. (1999) menggunakan primer gen cyt $b$ pada spesies sapi dan babi dinyatakan sensitif hingga konsentrasi 0,25 ng. Uji lain pada spesies sapi dan babi menggunakan primer gen 12S-, 16S- rRNA, dan tRNA-Val memiliki batas deteksi antara 0,0025-0,025 ng (Dalmasso et al., 2004), primer gen ND5 spesies sapi dan cyt $b$ spesies babi (Hossain et al., 2017) serta primer gen cyclic-GMP-phosphodiesterase pada spesies sapi dan beta-actin pada spesies babi dengan limit deteksi 0,003 ng (Iwobi et al., 2017). Pengujian sensitivitas untuk spesies anjing dan babi telah dilakukan oleh Liu et al. (2019) menggunakan primer gen ATPase 6 untuk 
Tabel 2. Sensitivitas simplex dan multiplex-PCR dengan variasi konsentrasi DNA

\begin{tabular}{lcccc}
\hline \multirow{2}{*}{ Spesies } & \multicolumn{2}{c}{ Simplex-PCR } & \multicolumn{2}{c}{ Multiplex-PCR } \\
\cline { 2 - 5 } & Sensitivitas $(\mathrm{ng} / \mathrm{\mu L})$ & Kode sampel & Sensitivitas $(\mathrm{ng} / \mu \mathrm{L})$ & Kode sampel \\
\hline Sapi & 0,001 & $\mathrm{~S} 6$ & 0,001 & $\mathrm{~W} 6$ \\
Anjing & 0,001 & $\mathrm{~N} 6$ & 0,001 & $\mathrm{~W} 6$ \\
Babi & 0,001 & $\mathrm{~B} 6$ & 0,001 & $\mathrm{~W} 6$ \\
Tikus & 0,001 & $\mathrm{~T} 6$ & 1 & $\mathrm{~W} 6$ \\
\hline
\end{tabular}

spesies anjing dan cyt $b$ untuk spesies babi memiliki limit deteksi $0.05 \mathrm{ng} / \mu \mathrm{L}$. Penggunaan primer lain dalam pengujian sensitivitas pada gen 16S rRNA untuk spesies anjing dan COI untuk spesies babi memiliki sensitivitas hingga $0.002 \mathrm{ng}$ ( $\mathrm{Li}$ et al., 2019), primer gen mitochondrial ATPase subunit 8 untuk spesies anjing dan babi dengan limit deteksi $0.03 \mathrm{ng}$ (Prusakova et al., 2018). Penelitian terhadap sensitivitas spesies anjing dan tikus menggunakan primer gen ATPase 6 serta ND5 untuk spesies babi memiliki sensitivitas 0.01 hingga 0.02 ng (Ali et al., 2015). Sensitivitas pada spesies tikus diuji menggunakan metode sandwich ELISA imunogen dan antibodi dengan limit deteksi 0,01 ug/L (Chen et al., 2020).

Penggunaan primer gen $12 \mathrm{~S}$ rRNA sebagai deteksi sensitivitas telah dilakukan pada spesies sapi dan babi, namun belum ditemukan deteksi sensitivitas untuk spesies anjing dan tikus. Penelitian ini apabila dibandingkan dengan penelitian terdahulu, primer gen $12 \mathrm{~S}$ rRNA lebih sensitif (Matsunaga et al., 1999; Dalmasso et al., 2004; Yin et al., 2009; Ali et al., 2015; Hossain et al., 2017; Iwobi et al., 2017; Prusakova et al., 2018; Liu et al., 2019; Li et al., 2019). Primer gen 12 S rRNA untuk spesies babi sama sensitif dengan primer gen COI yaitu 0,001 ng (Wang et al., 2019), kurang sensitif untuk spesies babi apabila dibandingkan dengan primer cyt $b$ oleh Lubis et al. (2018), dan kurang sensitif untuk spesies tikus oleh Chen et al. (2020).

\section{Amplifikasi Multiplex-PCR}

Hasil visualisasi sensitivitas multiplex-PCR primer gen $12 \mathrm{~S}$ rRNA tampak variasi tingkat terang (Gambar 2, kolom W1-W6). Visualisasi template DNA pada spesies sapi, anjing, babi dengan konsentrasi 25; 10; dan $1 \mathrm{ng} / \mu \mathrm{L}$ menghasilkan pita yang terang, serta pada konsentrasi 0,$1 ; 0,01$ hingga $0,001 \mathrm{ng} / \mathrm{\mu L}$ tampak redup namun dapat terdeteksi. Visualisasi pita DNA spesies tikus dengan konsentrasi 25; 10; dan
$1 \mathrm{ng} / \mu \mathrm{L}$ tampak terang hingga redup serta pada $0,1 \mathrm{ng} / \mathrm{\mu L}$ sudah tidak tampak pita DNA. Uji sensitivitas multiplex-PCR primer gen $12 \mathrm{~S}$ rRNA pada spesies sapi, anjing dan babi dinyatakan sensitif hingga konsentrasi $0,001 \mathrm{ng} /$ $\mu \mathrm{L}$ sedangkan pada pada spesies tikus sensitif hingga konsentrasi $1 \mathrm{ng} / \mu \mathrm{L}$.

Studi mengenai multiplex-PCR telah dikembangkan dan dibandingkan dengan penelitian terdahulu, metode multiplex-PCR primer gen $12 \mathrm{~S}$ rRNA untuk spesies sapi, anjing dan babi pada 0,001 ng/ $\mathrm{LL}$ dinyatakan lebih sensitif. Penggunaan multiplex end-point PCR primer gen $c y t b$ sebagai deteksi sensitivitas yang diamplifikasi pada enam spesies hewan menggunakan template DNA ditemukan limit deteksi sebesar 0,25 ng (Matsunaga et al., 1999), studi lain dilakukan oleh Dalmasso et al. (2004) dengan rancangan primer spesifik gen $12 \mathrm{~S}$ - dan 16S rRNA serta tRNA-Val adalah 0,0125 ng. Studi lain dilakukan oleh Li et al. (2019) yang berhasil mengembangkan dua tube multiplexPCR menggunakan primer gen 12S rRNA, 16S rRNA, ND2 dan COI pada 14 spesies hewan dengan limit deteksi 0,02 ng.

Perbedaan hasil amplifikasi pada uji sensitivitas simplex-PCR dan multiplex-PCR terdapat pada spesies tikus (Tabel 2). Keberhasilan multiplex-PCR dalam pengujian sensitivitas dipengaruhi oleh beberapa faktor, di antaranya adalah jumlah penggunaan primer, kompetisi antar primer, jumlah template DNA, jumlah nukleotida dan bahan lain sehingga reaksi pada multiplex-PCR semakin kompleks. Hambatan utama pada aplikasi dan standarisasi multiplex-PCR adalah sensitivitas yang relatif rendah serta efisiensi dan keseimbangan amplifikasi dari primer saat reaksi berlangsung (Ballin et al., 2009; Walker et al., 2003). Analisis oleh Walker et al. (2003) bahwa proses multiplex-PCR dan elektroforesis dapat mengakibatkan DNA terdagradasi sehingga efisiensi amplifikasi pada target spesies lebih rendah. 


\section{SIMPULAN}

Deteksi pemalsuan daging dengan metode simplex-PCR menggunakan primer gen $12 \mathrm{~S}$ rRNA dapat dilakukan dengan limit deteksi $0,001 \mathrm{ng} / \mu \mathrm{L}$ pada spesies sapi, anjing, dan babi. Metode multiplex-PCR menggunakan primer yang sama dapat mengamplifikasi daerah target pada spesies sapi, anjing, dan babi dengan limit deteksi $0,001 \mathrm{ng} / \mu \mathrm{L}$, sedangkan limit dekteksi untuk spesies tikus hanya $1 \mathrm{ng} / \mu \mathrm{L}$. Adopsi metode sensitivitas simplex- dan multiplex-PCR dapat digunakan sebagai solusi alternatif untuk studi halal dalam skala laboratorium.

\section{SARAN}

Perlu dilakukan penelitian serupa untuk spesies sapi, anjing, babi dan tikus menggunakan simplex-PCR maupun multiplex-PCR primer gen $12 \mathrm{~S}$ rRNA dengan konsentrasi di bawah $0,001 \mathrm{ng} / \mu \mathrm{L}$.

\section{UCAPAN TERIMA KASIH}

Penelitian didanai oleh Kementerian Ristek/ BRIN dengan skim hibah Penelitian Dasar Kompetitif Nasional (PDKN) dengan nomor surat keputusan (SK): 208/SP2H/AMD/LT/ DRPM/2020 dan nomor kontrak: 112/UN27.21/ HK/2020.

\section{DAFTAR PUSTAKA}

Ali ME, Razzak MA, Hamid SB. 2015. Multiplex PCR assay for the detection of five meat species forbidden in Islamic foods. Food Chem 177: 214-224.

Ballin NZ, Vogensen FK, Karlsson AH. 2009. Species determination - can we detect and quantify meat adulteration. Meat Sci 83: 165-174.

Cahyadi M, Taufik IM, Pramono A, Abdurrahman ZH. 2019. Development of mitochondrial $12 \mathrm{~S}$ rRNA gene for identification of dog and rat in beef using multiplex-PCR. J Indones Trop Anim Agric 44(1): 10-18.

Cahyadi M, Puruhita, Barido FH, Hertanto BS. 2018. Specific primer design of mitochondrial $12 \mathrm{~S}$ rRNA for species identification in raw meats. IOP Conf Ser Earth Environ Sci 102(1): 12-38.

Cahyadi M, Wibowo T, Pramono A, Abdurrahman ZH. 2020. A novel multiplexPCR assay to detect three non-halal meats contained in meatball using mitochondrial $12 \mathrm{~S}$ rRNA gene. Food Sci Anim Resour 40(4): 628-635.

Cawthorn DM, Steinman HA, Witthuhn RC. 2011. Comparative study of different methods for the extraction of DNA from fish species commercially available in South Africa. Food Control 22(2): 231-244.

Chen X, Ran D, Zeng L, Xin M. 2020. Immunoassay of cooked wild rat meat by ELISA with a highly specific antibody targeting rat heat resistant proteins. Food Agric Immunol 31: 533-544.

Dalmasso A, Fontanella E, Piatti P, Civera T, Rosati S, Bottero MT. 2004. A multiplexPCR assay for the identification of animal species in feedstuffs. Mol Cell Probes 18(2): 81-87.

Demeo S. 1996. Mathematically modeling dilution. Chem Educator 1(1): 1-5.

El Sheikha AF, Mokhtar NF, Amie C, Lamasudin DU, Isa NM, Mustafa S. 2017. Authentication technologies using DNAbased approaches for meats and halal meats determination. Food Biotechnol 31(4): 281315 .

Hossain MAM, Ali ME, Sultana S, Asing, Bonny SQ, Kader MA, Rahman MA. 2017. Quantitative tetraplex real-time polymerase chain reaction assay with taqman probes discriminates cattle, buffalo, and porcine materials in food chain. J Agric Food Chem 65: 3975-3985.

Iwobi A, Sebah D, Spielmann G, Maggipinto M, Schrempp M, Kraemer I, Gerdes L, Busch U, Huber I. 2017. A multiplex real-time PCR method for the quantitative determination of equine (horse) fractions in meat products. Food Control 74: 89-97.

Kumar A, Kumar RR, Sharma BD, Gokulakrishnan P, Mendiratta SK, Sharma D. 2015. Identification of species origin of meat and meat products on the DNA basis: a review. Crit Rev Food Sci Nutr 55(10): 1340-1351. 
Kumparan Bisnis. 2018. Bisnis daging anjing raup untung $\mathrm{Rp}$ 11,4 Miliar sebulan. https:/ /cutt.ly/6jDSoPS. [Diakses 13 Januari 2021].

Li J, Li J, Xu S, Xiong S, Yang J, Chen X, Wang S, Qiao X, Zhou T. 2019. A rapid and reliable multiplex PCR assay for simultaneous detection of fourteen animal species in two tubes. Food Chem 295: 395-402.

Liu WW, Tao J, Xue M, Ji JG, Zhang YH, Zhang LJ, Sun WP. 2019. A multiplex PCR method mediated by universal primers for the identification of eight meat ingredients in food products. Eur Food Res Technol 245: 2385-2392.

Lubis H, Salihah NT, Norizan NA, Hossain MM, Ahmed MU. 2018. Fast and sensitive realtime PCR-based detection of porcine DNA in food samples by using Evagreen dye. Food Sci Technol Res 24(5): 803-10.

Matsunaga T, Chikuni K, Tanabe R, Muroya S, Shibata K, Yamada J, Shinmura Y. 1999. A quick and simple method for the identification of meat species and meat products by PCR assay. Meat Sci 51: 143148.

Naaum AM, Shehata HR, Chen S, Li J, Tabujara N, Awmack D, Lutze-Wallace C, Hanner R. 2018. Complementary molecular methods detect undeclared species in sausage products at retail markets in Canada. Food Control 84: 339-344.

Nida L, Pisestyani H, Basri C. 2002. Studi kasus: pemalsuan daging sapi dengan daging babi hutan di Kota Bogor. J Kajian Veteriner 8(2): 121-30.

PIHPS Nasional. 2021. Laporan harian perkembangan harga pangan. https:// cutt.ly/GjDStba. [Diakses 13 Januari 2021].

Prusakova OV, Glukhova XA, Afanas'eva GV, Trizna YA, Nazarova L, Beletsky IP. 2018. A simple and sensitive two-tube multiplex PCR assay for simultaneous detection of ten meat species. Meat Sci 137: 34-40.

Spink J, Moyer DC. 2011. Defining the public health threat of food fraud. J Food Sci 76: R157-R163.

Tribun Manado. 2020. Harga daging babi tembus Rp 50 ribu per kg, 'kami sesuaikan dengan harga yang dijual peternak. https://cutt.ly/ NjDA3yC. [13 Januari 2021].

Walker JA, Hughes DA, Anders BA, Shewale J, Sinha SK, Batzer MA. 2003. Quantitative intra-short interspersed element PCR for species-specific DNA identification. Anal Biochem 316: 259-269.

Wang LP, Hang XR, Geng RQ. 2019. Molecular detection of adulteration in commercial buffalo meat products by multiplex PCR assay. Food Sci Technol 39: 344-348.

Yin RH, Bai WL, Wang JM, Wu CD, Dou QL, Yin RL, Luo GB. 2009. Development of an assay for rapid identification of meat from yak and cattle using polymerase chain reaction technique. Meat Sci 83(1): 38-44. 